\title{
MELPHALAN-INDUCED CYTOTOXICITY IN THE BONE MARROW OF RATS BY FLOW CYTOMETRY MEASUREMENTS
}

\author{
B. I. Gerashchenko', I. M. Todor', O. O. Shevchuk' ${ }^{2}$, V. G. Nikolaev ${ }^{1}$ \\ 1 - R. E. KAVETSKY INSTITUTE OF EXPERIMENTAL PATHOLOGY, ONCOLOGY AND RADIOBIOLOGY, \\ NATIONAL ACADEMY OF SCIENCES OF UKRAINE, KYIV, UKRAINE \\ 2 - I. HORBACHEVSKY TERNOPIL STATE MEDICAL UNIVERSITY, TERNOPIL, UKRAINE
}

\begin{abstract}
Background. Bone marrow (BM) that contains hematopoietic cells of various lineages is a sensitive target for a number of cytotoxic agents including chemotherapy drugs.

Objective. Flow cytometry (FCM) was chosen to test cytotoxicity in BM of rats, that received melphalan either intravenously (i.v.) or intraperitoneally (i.p.).

Methods. One group of rats received melphalan i.v. $\left(3 \mathrm{mg} / \mathrm{kg}\right.$ ) followed by the BM examination on the $3^{\text {rd }}$ and $7^{\text {th }}$ day after drug administration, whereas another group of animals received this drug i.p. in total doses of 9 and $15 \mathrm{mg} / \mathrm{kg}$ followed by the BM examination on the next day after the $3^{\text {rd }}$ and $5^{\text {th }}$ injection of the drug. BM cells were stained with acridine orange and analyzed by FCM. Cytotoxicity was assessed by determining the percentage of total nucleated cells (TNC\%) among the whole BM cell population and by determining the percentage of polychromatic erythrocytes (PCE\%) among the whole population of enucleated erythrocytes.

Results. Regardless of the dose and regimen of melphalan administration, either i.v. or i.p. administered drug caused a significant reduction of TNC\%. On the average, the i.p. administered drug resulted in about 2.0fold decrease of TNC\% $(P<0.05)$, while the i.v. administered drug resulted in about 1.3-fold decrease of TNC\% $(P<0.05)$. As for enucleated erythrocytes, the i.p. administered drug resulted in about 1.4-fold decrease of PCE\% $(P<0.05)$, whereas the i.v. administered drug did not cause any changes in the PCE\%.

Conclusions. Under these experimental conditions, i.p. administrated melphalan is considerably more cytotoxic than i.v. administered melphalan. This cytotoxic effect is preferentially due to impaired erythropoiesis.

KEY WORDS: bone marrow; melphalan; cytotoxicity; flow cytometry; polychromatic erythrocytes; total nucleated cells.
\end{abstract}

\section{Introduction}

The anti-tumor effect of alkylating chemotherapeutics primarily attributes to their ability to covalently bind DNA via alkyl groups causing intra- and inter-strand crosslinks [1]. Any alkylating drug by induction of DNA lesions can affect the replication of actively proliferating cells [2]. Moreover, an impaired replication or repair of crosslinked DNA is likely to lead to cell death [3]. Although alkylating drugs can specifically target proliferating cells, they are not cell cycle phase-specific, and for this reason, cell death is believed to directly correlate with the dose of the drug [4]. An alkylating agent melphalan (known as interstrand DNA-crosslinker [1]), which is mainly used for treatment of multiple myeloma, ovarian carcinoma, breast cancer, childhood neuroblastoma, and poly-

Corresponding author: Bogdan I. Gerashchenko, M.D., Ph.D. R. E. Kavetsky Institute of Experimental Pathology, Oncology and Radiobiology, National Academy of Sciences of Ukraine, Vasylkivska 45, Kyiv 03022, Ukraine

Phone: +380442571177

FAX: +380442581656

E-mail: biger63@yahoo.com cythaemia vera, however, may cause complications, particularly acute myeloid leukemia in the decade after therapy [5]. Melphalan-treated individuals with an increased level of chromosomal aberrations in the peripheral blood lymphocytes are at risk of developing cancer later in life [5]. In the experimental animals, melphalan induces cancer of various localizations [5], and regardless of the route of administration, it is apparently genotoxic [6-10].

In the present work, flow cytometry (FCM) has been chosen to examine cytotoxicity in the bone marrow (BM) of rats that received melphalan either intravenously (i.v.) or intraperitoneally (i.p.). BM that contains hematopoietic cells of various lineages is a sensitive object of cytotoxic studies. As for the FCM, this technique is indispensable in many areas of biology and medicine not only because of its high-speed analysis, but also because of its ability to accurately discriminate cells of various types. The FCM usually discriminates cells based on their size, intracellular granularity and selective/ specific fluorescence labeling [11]. This unique 
advantage of FCM can be applied for the study of cytotoxic effects in BM cells of different lineages and maturation stages. Here we use a simple and reliable FCM approach for the analysis of BM cells stained with acridine orange (AO), a metachromatic dye that simultaneously interacts with DNA and RNA producing at $\lambda=488 \mathrm{~nm}$ the dual emission spectra with peaks at $530 \mathrm{~nm}$ and $640 \mathrm{~nm}$, respectively [12]. This proposed approach by Criswell et al. [13] allows assessing cytotoxicity particularly in erythropoietic cells based on detection of differences in AO uptake between polychromatic erythrocytes (PCE) and normochromatic erythrocytes (NCE). Redistribution of erythrocytes towards NCE is indicative of cytotoxic effect. Suzuki et al. [14] suggested that the reduced $\mathrm{PCE} / \mathrm{NCE}$ ratio is most likely caused by elevation of NCE population as a result of mutageninduced rapid differentiation and multiplication or enucleation of erythroblasts which remained in the BM instead of entering the peripheral blood steam. On the other hand, Von Lebedur and Shcmid [15] claimed that as a result of mutagen-induced partial depletion of the marrow cavities of nucleated blood cell precursors the newly formed erythrocytes can be retained along with inundation with peripheral blood.

\section{Methods \\ Experimental animals and administration of melphalan}

Adult outbred female rats (140-160 g) were taken from the animal house of R. E. Kavetsky Institute of Experimental Pathology, Oncology and Radiobiology (IEPOR) of the National Academy of Sciences of Ukraine (Kyiv, Ukraine). Immediately before the i.v. or i.p. injections, 0.6 $\mathrm{mg} / \mathrm{ml}$ solution of melphalan (Alkeran ${ }^{\circledR}$ produced by GlaxoSmithKline, UK) was prepared by diluting $20 \mathrm{mg} / \mathrm{ml}$ solution of this drug dissolved in acidified ethanol (96\% ethanol and $12 \mathrm{~N}$ $\mathrm{HCl}$ mixed in the ratio of 150:1) with saline. One group of animals $(n=3)$ was subjected to i.v. injection (via tail vein) of melphalan of a single dose of $3 \mathrm{mg} / \mathrm{kg}$ followed by the BM examination on the $3^{\text {rd }}$ and $7^{\text {th }}$ day after drug administration. Another group of animals $(n=3)$ was subjected to i.p. injections of melphalan every other day with single doses of $3 \mathrm{mg} / \mathrm{kg}$ followed by the BM examination on the next day after $3^{\text {rd }}$ and $5^{\text {th }}$ injection of the drug (total doses were 9 and $15 \mathrm{mg} / \mathrm{kg}$, respectively). Since melphalan after i.p. administration is assumed to be less readily delivered to the target tissue than after i.v. administration due to its gradual absorption into blood, this prompted us to increase the total dose of melphalan for delivery via i.p. route. There was also a group of animals that did not receive the drug at all (the intact control, $n=3$ ). The study with animals was performed according to the regulations of the Ethics Committee.

\section{BM isolation, specimen processing and}

\section{fixation}

The femur removal and BM isolation procedures were in general performed as proposed [13]. The BM cells were thoroughly flushed from the femur with $4 \mathrm{ml}$ of RPMI-1640 (PharmBiotek, Ukraine) and immediately placed in a refrigerator $\left(+4-6^{\circ} \mathrm{C}\right)$. At this temperature, the BM cells were kept no longer than 1.5 hour before they were resuspended by vortexing and centrifuged at $300 \times \mathrm{g}$ for $5 \mathrm{~min}$. Specimen processing and fixation procedures were mainly performed according to the protocol [13]. The supernatant was discarded with further washing the cells in $5 \mathrm{ml}$ of PBS using centrifugation at $300 \times \mathrm{g}$ for $5 \mathrm{~min}$. The supernatant was discarded with further resuspension of cells in $2 \mathrm{ml}$ of PBS by vortexing. Cell aggregates were dissociated by gentle syringing of the suspension through a 21-gauge needle. While vigorous vortexing, $0.2 \mathrm{ml}$ of cell suspension was added to $5 \mathrm{ml}$ of fixative solution: $1 \%$ glutaraldehyde $(\mathrm{v} / \mathrm{v})$ in PBS with $30 \mu \mathrm{g} / \mathrm{ml}$ of SDS (Merck, Germany). The cells were fixed for $5 \mathrm{~min}$ and then centrifuged at $300 \times \mathrm{g}$ for $5 \mathrm{~min}$. The supernatant was removed with further resuspension of cells in $0.5 \mathrm{ml}$ of PBS.

\section{Fluorescence staining}

This procedure with slight modification was performed in accordance with the protocol [13]. Solution A was prepared by dissolving of the following components in $100 \mathrm{ml}$ (final volume) of distilled $\mathrm{H}_{2} \mathrm{O}: 0.1 \mathrm{ml}$ Triton X-100 (Loba Chemie, Austria), $8 \mathrm{ml} 1.0 \mathrm{~N} \mathrm{HCl}$, and $0.877 \mathrm{~g}$ $\mathrm{NaCl}$. Solution $\mathrm{B}$ was prepared by mixing of 37 $\mathrm{ml} 0.1 \mathrm{M}$ citric acid with $63 \mathrm{ml} 0.2 \mathrm{M} \mathrm{Na}_{2} \mathrm{HPO}_{4}$ ( $p H$ 6.0) and adding $0.877 \mathrm{~g} \mathrm{NaCl}, 34 \mathrm{mg}$ EDTA disodium salt (Sigma, USA), and $0.6 \mathrm{ml}$ of acridine orange (AO; Sigma) stock solution $(1 \mathrm{mg} / \mathrm{ml})$. The fixed cells $(0.2 \mathrm{ml}$ of cell suspension) were added to the mixture of Solutions $A$ and $B$ ( 0.4 and $1.2 \mathrm{ml}$, respectively) that was chilled on ice in a $12 \times 75 \mathrm{~mm}$ centrifuge tubes. While shaking, the cells were stained on ice for $30 \mathrm{~min}$ in the dark. Then they were centrifuged at $300 \times \mathrm{g}$ for $5 \mathrm{~min}$. After the supernatant was carefully removed, $1 \mathrm{ml}$ of PBS was added to resuspend the cells. Before FCM, cell suspension 
was gently syringed through a 21-gauge needle to obtain a suspension of single cells.

\section{FCM analysis}

The samples were analyzed using an EPICS XL flow cytometer (Beckman Coulter, USA) equipped with a 15-mW argon-ion laser $(488 \mathrm{~nm})$. The forward light scatter (FSC; related to cell size) and side $\left(90^{\circ}\right)$ light scatter (SSC; related to intracellular granularity) signals were collected in a linear mode. The fluorescence signals of DNA- and RNA-bound AO were collected respectively in the green fluorescence channel (FL1) through a 525/10-nm band-pass filter and in the far-red fluorescence channel (FL4) through a 675/10-nm band-pass filter using a logarithmic amplification [13]. The acquisition rate was 500-1000 cells per second. At least $1.0 \times 10^{5}$ events were collected for each sample. The analysis of the data was performed by publicly available software "WinMDI" developed by Dr. J. Trotter (http://www.cyto. purdue.edu/flowcyt/software/Winmdi.htm). The cells were gated on FSC-Height vs. SSCHeight histograms to eliminate debris and aggregates from analysis (not presented here), although microscopic observation showed that their numbers were extremely low. The parameters that were examined are as follows: 1) percentage of total nucleated cells (TNC) of all BM cells, including enucleated cells such as PCE and NCE (this parameter is further denoted as TNC\%); 2) percentage of PCE of all enucleated erythrocytes (denoted as PCE\%). The reason why $\mathrm{TNC}_{\%}$ was also examined is based on the fact that the nucleated erythroid cells are most numerous in the BM, and accordingly, suppressed erythropoiesis may affect TNC\%. Thus, the decreased TNC\% and PCE\% (particularly PCE\%) can be indicative of inhibited division and maturation of nucleated erythroid cells, the fact that has been previously reported [13-16]. The populations of TNC, PCE and NCE that demonstrate significant differences in $\mathrm{AO}$ uptake were determined on a FL1-Height vs. FL4Height histogram (Fig. 1A).

\section{Statistical analysis}

Probability values with $p<0.05$ were considered statistically significant. The distribution of indices was estimated by using the ShapiroWilk Normality Test. The statistical significance of the differences between the means was assessed by the Mann-Whitney-test and ANOVA-test using Origin 7.5 software (OriginLab Corporation, USA).

\section{Results}

Regardless of the dose and regimen of melphalan administration, i.v. delivered melphalan did not cause any significant changes in the PCE\%, whereas i.p. delivered drug on the average resulted in about 1.4-fold decrease of PCE\% ( $p<0.05$, compared with the control; Fig. 2).

As for TNC, melphalan administered either i.v. or i.p. resulted in a significant decrease of
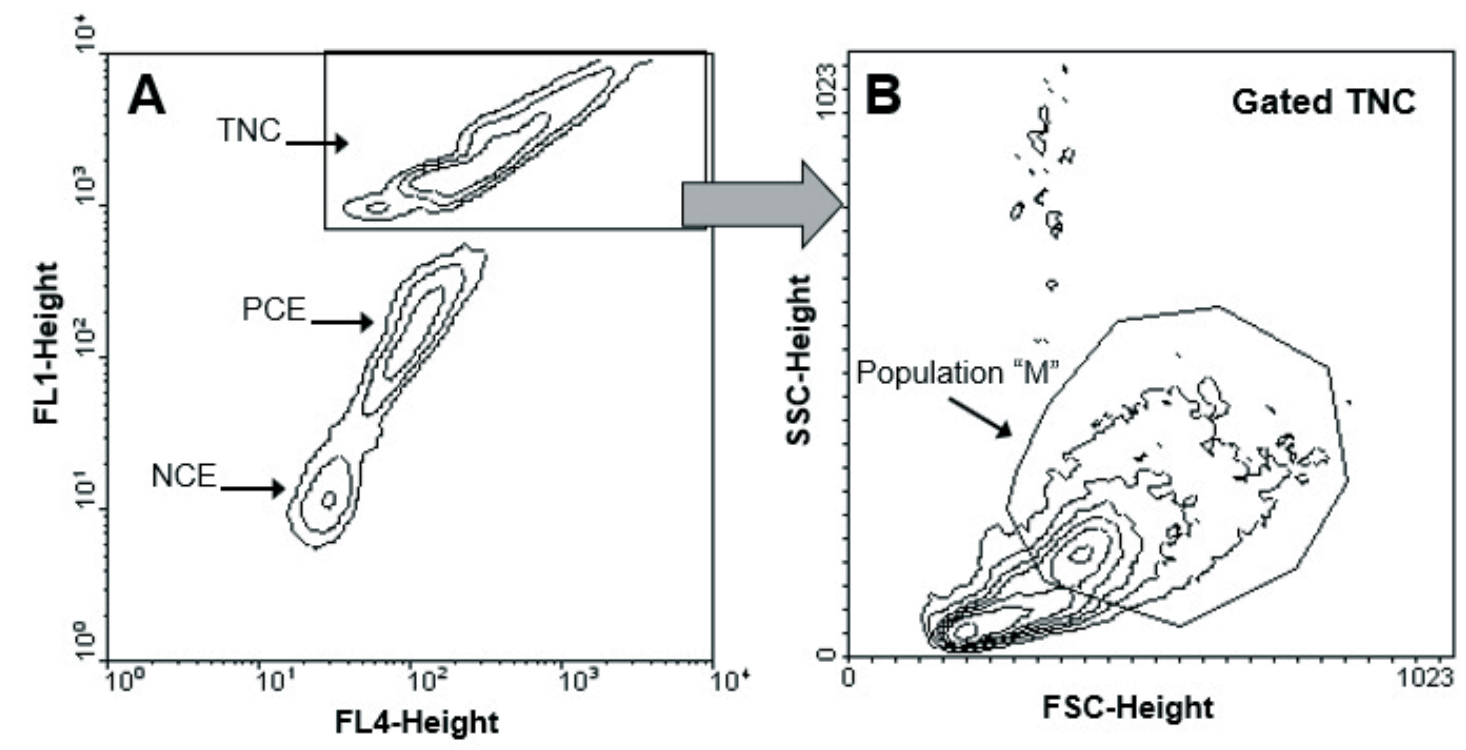

Fig. 1A. Example of FCM determination of TNC, PCE, NCE populations in AO-stained unfractionated BM cells (BM cells were isolated from the femur of the control intact rat).

Fig. 1B. Population of TNC gated on a FL1-Height vs. FL4-Height histogram (framed by the rectangular window; panel A) is shown on a FSC-Height vs. SSC-Height histogram to analyze the population ' $\mathrm{M}$ ' Comprised of the vast majority of myeloid cells. 


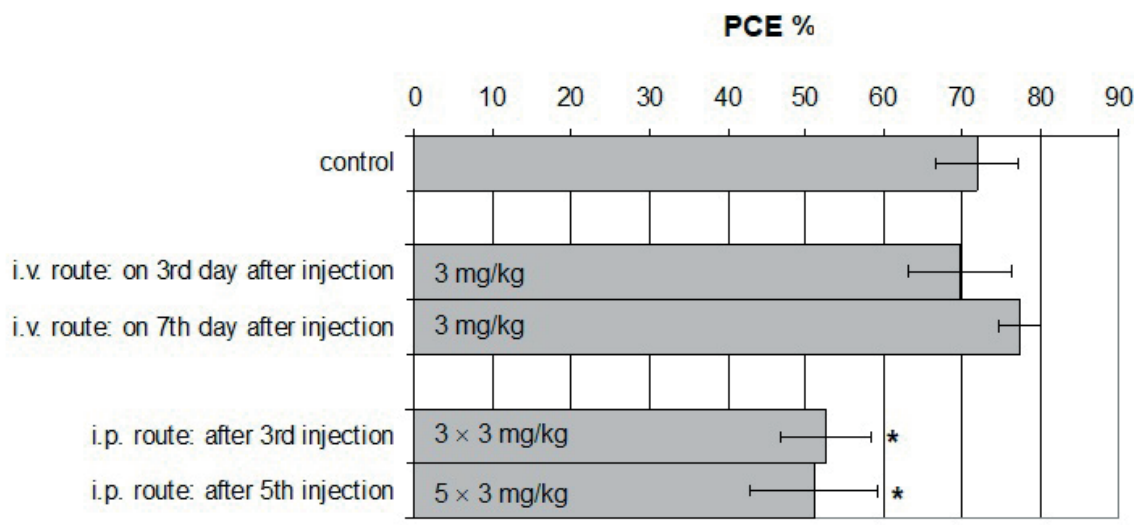

Fig. 2. Effect of variously administered melphalan on the PCE\%. The data presented are the mean \pm standard error of the mean. Each group consists of three animals. Asterisks (*) show significant differences if compared with the control $(\mathrm{p}<0.05)$.

TNC\% $(p<0.05$, compared with the control Fig. 3). On the average, after i.p. and i.v. drug delivery there was a 2.0 -fold and 1.3-fold decrease of TNC\%, respectively (Fig. 3). Obviously, melphalan after several i.p. administrations $(3 \times 3 \mathrm{mg} / \mathrm{kg}$ or $5 \times 3 \mathrm{mg} / \mathrm{kg}$ ) was more cytotoxic than after a single i.v. administration ( $3 \mathrm{mg} / \mathrm{kg}$ ). However, increasing the dose of i.p. injected melphalan up to $5 \times 3 \mathrm{mg} / \mathrm{kg}$ did not result in more significant cytotoxic effect. Perhaps, at lower dose of this drug $(3 \times 3 \mathrm{mg} / \mathrm{kg})$ the maximal effect could be reached. As for the i.v. delivery of melphalan, we did expect that this route of drug administration would be more efficient in terms of causing cytotoxicity in the BM. That is why a single minimal dose of melphalan $(3 \mathrm{mg} / \mathrm{kg}$ ) was chosen for this route of delivery.

Although the aforementioned findings seem to be indicative of suppressed proliferation of erythroid cells, particularly in case of i.p. administered melphalan, it cannot be certainly claimed that proliferation of myeloid cells remains unaffected. Since myeloid cells as well as erythroid cells are numerous in the BM [17], one can expect that the drug-induced suppression in proliferation of these cells may also contribute to significant fluctuations of TNC\%. To address this issue, we were able to identify within TNC the population of cells (population ' $M$ '; Fig. 1B), the vast majority of which are likely to be myeloid. This assumption is simply based on the evidence that they are generally large with a specific intracellular granularity [17-19]. In FCM, cell size usually correlates with the FSC, while intracellular granularity correlates with the SSC [11]. The percentage of population ' $M$ ' of the whole TNC population (denoted as population ' $\mathrm{M}$ '\%) was similar to that revealed microscopically by the classic morphology-based evaluation (date not shown). Notably, i.p. administered melphalan on the average caused a 1.3-fold increase of the portion of population "M" (Fig. 4) with a concordant decrease of PCE\% (Fig. 2). However, together with the fact that the i.p. delivered drug resulted in a 2-fold decrease of TNC\% (Fig. 3) one can assume that granulopoiesis is likely be affected but certainly to a lesser extent then erythropoiesis. As for the i.v. delivered TNC \%

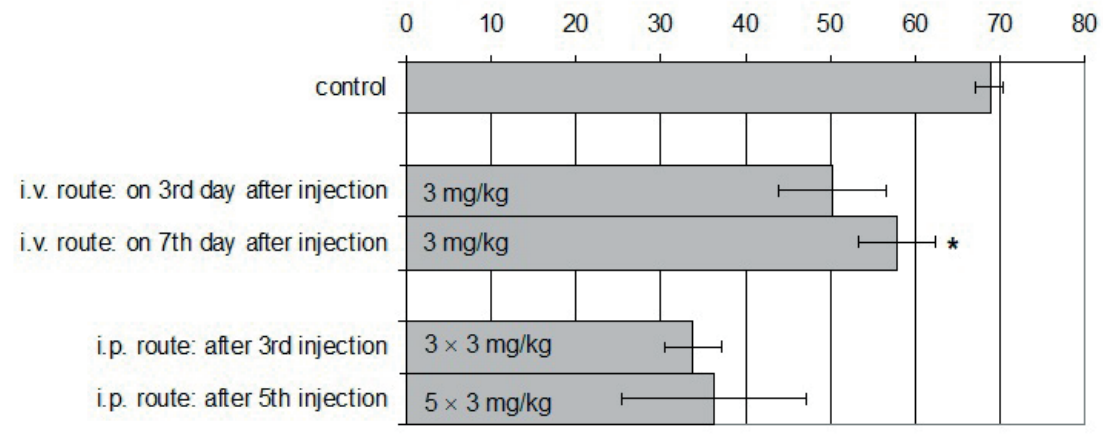

Fig. 3. Effect of variously administered melphalan on the TNC\%. The data presented are the mean \pm standard error of the mean. Each group consists of three animals. Asterisk (*) shows significant difference if compared with the control $(p<0.05)$. 


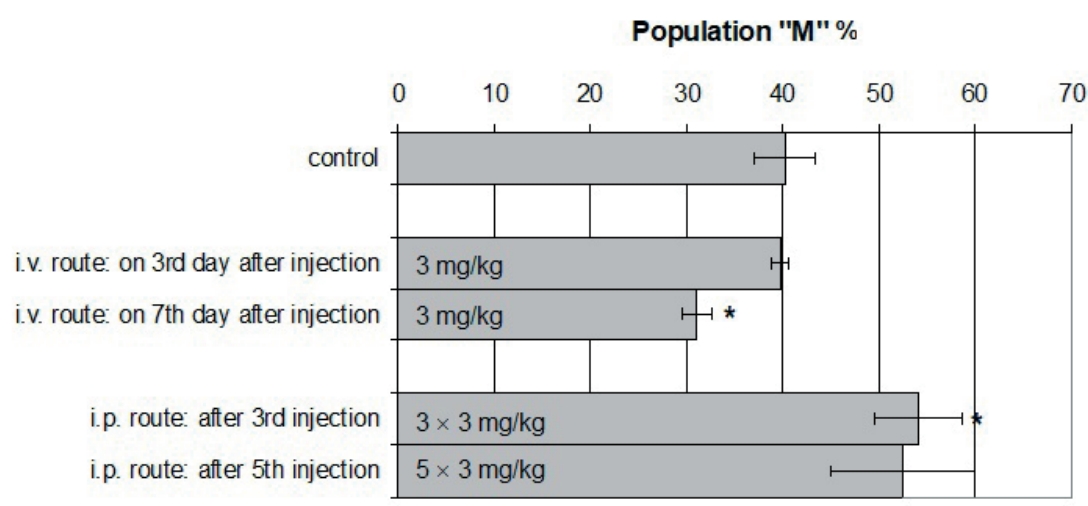

Fig. 4. Effect of variously administered melphalan on population ' $M$ '\%. The data presented are the mean \pm standard error of the mean. Each group consists of three animals. Asterisks (*) show significant differences if compared with the control $(p<0.05)$.

drug, there was a 1.3-fold decrease of population "M"\%, but only on the 7th day of its injection $(p<0.05$, compared with the control; Fig. 4). This decrease of population ' $\mathrm{M}$ '\% was accompanied by a slight increase of PCE\% on the same day after i.v. drug administration (Fig. 2). Perhaps, on this day (the $7^{\text {th }}$ day) after i.v. drug administration the erythroid cells recovered faster than myeloid cells.

\section{Discussion}

Regrettably, there is lack of reports concerning cytotoxic or genotoxic effects in the BM of rats caused by melphalan delivered either i.v. or i.p. Instead, it was reported that the rats that intramuscularly received this alkylating agent of a single dose of $1 \mathrm{mg} / \mathrm{kg}$ developed a transient but significant increase of chromosomal aberrations in BM cells peaking on the next day after the drug administration (but there were almost no aberrations on the second day after the drug administration, similar to the control), while increasing the dose up to $10 \mathrm{mg} /$ $\mathrm{kg}$ led to the absence of mitotic figures, which is indicative of significant BM suppression [6].

Thus based on the results of our research, one can assume that erythropoiesis is more readily affected by melphalan than granulopoiesis was, but erythropoiesis seemed to be recovered faster than granulopoiesis. Apparent erythropoietic cytotoxicity in the BM of rats was shown to be caused by another alkylating drug cyclophosphamide that at the range of doses $5-40 \mathrm{mg} / \mathrm{kg}$ resulted in a significant increase of myeloid/erythroid ratios on the second day after i.p. drug delivery $[20,21]$.
Erythroid cells were shown to be very sensitive with respect to ionizing radiation (IR), DNA damaging agent of a physical origin [22, 23]. For example, as a result of a whole-body irradiation of rats with the dose of X-rays about 7.0 Gy $\left(\mathrm{LD}_{50}\right)$ the erythroid cells appeared to be significantly more sensitive than the myeloid cells; however, erythropoiesis began recovering much earlier than granulopoiesis (obvious regeneration was first clearly observed on the $12^{\text {th }}$ day after irradiation as evidenced by areas of erythropoiesis) [21]. Notably, the cytotoxic effect of any alkylating agent is referred to as 'radiomimetic' because IR and alkylating agents are similar in terms of inducing cell death mechanisms (both of them induce the mitotic catastrophe) [24, 25]. Interestingly, as for melphalan, its dose-response relationship resembles that for IR as evidenced by the shape of the survival curve [24]. A series of studies has been initiated towards tackling melphalaninduced BM suppression [26, 27], and, in this regard, monitoring of BM recovery by $\mathrm{FCM}$ could be helpful as well.

\section{Conclusions}

Under the present experimental conditions, i.p. administrated melphalan is considerably more cytotoxic than i.v. administered melphalan, and this effect is preferentially due to impaired erythropoiesis. Granulopoiesis is less readily affected by the melphalan than erythropoiesis, but on the other hand, granulopoiesis, if affected, is slower recovering than erythropoiesis. It is expected that the FCM findings of this study could be helpful for experimental oncologists, who design experiments on antitumor effects of melphalan with less side effects. 


\title{
ОЦІНКА МЕЛФАЛАН-ІНДУКОВАНОЇ ЦИТОТОКСИЧНОСТІ НА КЛІТИНИ КІСТКОВОГО МОЗКУ ЩУРІВ ЗА ДАНИМИ ПРОТОЧНОЇ ЦИТОМЕТРІЇ
}

\author{
Б. І. Геращенко', І. М. Тодор ${ }^{1}$, О. О. Шевчук², В. Г. Ніколаєв ${ }^{1}$ \\ 1 - ІНСТИТУТ ЕКСПЕРИМЕНТАЛЬНОЇ ПАТОЛОГІЇ, ОНКОЛОГІЇ І РАДІОБІОЛОГІЇ ІМЕНІ Р. Є. КАВЕЦЬКОГО \\ НАН УКРАЇНИ, КИЇ̈, УКРӒ̈НА \\ 2 - ТЕРНОПІЛЬСЬКИЙ ДЕРЖАВНИЙ МЕДИЧНИЙ УНІВЕРСИТЕТ ІМЕНІ І. Я. ГОРБАЧЕВСЬКОГО,
}

ТЕРНОПIЛЬ, УКРАЇНА

\begin{abstract}
Вступ. Кістковий мозок, як основний орган гемопоезу, особливо чутливий до впливу цілого ряду цитотоксичних протипухлинних лікарських засобів.

Мета роботи: за допомогою проточної цитометрії встановити прояви цитотоксичності на клітини кісткового мозку щурів за умов довенного та інтраперитонеального введення мелфалану.

Методи. Кістковий мозок щурів досліджували на 3-ю та 7-у доби після довенного введення мелфалану в дозі 3 мг/кг; а також на наступний день після 3-їта 5-ї ін'єкцій препарату при його інтраперитонеальному застосуванні (при досягненні кумулятивної дози 9 та 15 мг/кг). Клітини кісткового мозку забарвлювали акридиновим помаранчевим та аналізували за допомогою проточної цитометрії. Цитотоксичність оцінювали за відсотком загальної кількості ядерних клітин (ЯК\%), а також за відсотком поліхроматофільних еритроцитів (ПХЕ\%) у складі всіх без'ядерних еритрочитів.

Результати. Незважаючи на шлях введення та обрану дозу, мелфалан викликав достовірне зниження ЯК\%. В середньому, показник ЯК\% знижувався у 2 рази при інтраперитонеальному введенні $(p<0.05)$ та в 1.3 рази - при довенному (p<0.05). Стосовно без'ядерних еритроцитів, ПХЕ\% знижувався в 1.4 рази при інтраперитонеальнему введенні $(p<0.05)$, тоді як при довенному введенні цей показник залишався без змін.

Висновки. В даних експериментальних умовах, на відміну від довенного застосування, інтраперитонеально введений мелфалан виявився більш цитотоксичним, переважно за рахунок порушень еритропоезу.

КЛЮЧОВІ СЛОВА: кістковий мозок; мелфалан; цитотоксичність; проточна цитометрія; поліхроматофільні еритроцити; ядерні клітини.
\end{abstract}

\section{References}

1. Hurley LH. DNA and its associated processes as targets for cancer therapy. Nat Rev Cancer 2002; 2: 188-200. doi: 10.1038/nrc749.

2. Chabner BA, Wilson W, SupkoJ. Pharmacology and toxicity of antineoplastic drugs. In: Beutler $E_{\text {, }}$ Lichtman MA Coller BS, Kipps TJ, Seligsohn U, eds. Williams Hematology, 6th edition. New York: McGraw-Hill, 2001: 185-200.

3. Damia G, D'Incalci M. Mechanisms of resistance to alkylating agents. Cytotechnology 1998; 27: 165173. doi: 10.1023/A:1008060720608.

4. Malhotra V, Perry MC. Classical chemotherapy: Mechanisms, toxicities and the therapeutic window. Cancer Biol Ther 2003; 2 (Suppl. 1): S2-S4. doi: 10.4161/cbt.199.

5. IARC. Melphalan. IARC Monogr Eval Carcinog Risk Hum 2012; 100A: 107-117.

6. Wantzin GL, Jensen MK. The induction of chromosome abnormalities by melphalan in rat bone marrow cells. Scand J Haemat 1973; 11: 135-139. doi: 10.1111/j.1600-0609.1973.tb00107.x.

7. Shelby MD, Gulati DR, Tice RR, Wojciechowski JP. Results of tests for micronuclei and chromosomal aberrations in mouse bone marrow cells with the human carcinogens 4-aminobiphenyl, treosul- phan, and melphalan. Environ Mol Mutagen 1989; 13: 339-142. doi: 10.1002/em.2850130410.

8. Generoso WM, Witt KL, Cain KT, Hughes L, Cacheiro NLA, Lockhart A-MC, et al. Dominant lethal and heritable translocations tests with chlorambucil and melphalan in male mice. Mutat Res 1995; 345: 167-180. doi: 10.1016/0165-1218(95)90052-7.

9. Ranaldi R, Palma S, Tanzarella C, Lascialfari A, Cinelli S, Pacchierotti F. Effect of p53 haploinsufficiency on melphalan-induced genotoxic effects in mouse bone marrow and peripheral blood. Mutat Res 2007; 615: 57-65. doi: 10.1016/j.mrfmmm.2006.10.001.

10. Sgura A, De Amicis A, Stronati L, Cinelli S, Pacchierotti F, Tanzarella C. Chromosome aberrations and telomere length modulation in bone marrow and spleen cells of melphalan-treated p53+/ mice. Environ Mol Mutagen 2008; 49: 467-475. doi: 10.1002/ em.20405.

11. Ormerod MG (editor). Flow cytometry: a practical approach, 3rd ed. Oxford: University Press; 2000, 296 p.

12. Traganos F, Darzynkiewicz Z, Sharpless T, Melamed MR. Simultaneous staining of ribonucleic and deoxyribonucleic acids in unfixed cells using acridine orange in a flow cytofluorometric system. J 
Histochem Cytochem 1977; 25: 46-56. doi: 10.1177/25.1.64567.

13. Criswell KA, Krishna G, Zielinski D, Urda GA, Theiss JC, Juneau $P$, et al. Use of acridine orange in: flow cytometric evaluation of erythropoietic cytotoxicity. Mutat Res 1998; 414: 49-61. doi: 10.1016/ S1383-5718(98)00041-2.

14. Suzuki Y, Nagae Y, Li J, Sakaba H, Mozawa K, Takahashi A, et al. The micronucleus test and erythropoiesis. Effects of erythropoietin and mutagen on the ratio of polychromatic to normochromatic erythrocytes ( $\mathrm{P} / \mathrm{N}$ ratio). Mutagenesis 1989; 4: 420424. doi: 10.1093/mutage/4.6.420.

15. Von Ledebur M, Schmid W. The micronucleus test: Methodological aspects. Mutat Res 1973; 19: 109-117. doi: 10.1016/0027-5107(73)90118-8.

16. Shcmid W. The micronucleus test. Mutat Res 1975; 31: 9-15. doi: 10.1016/0165-1161(75)90058-8.

17. Bolliger AP. Cytologic evaluation of bone marrow in rats: indications, methods, and normal morphology. Vet Clin Pathol 2004; 33: 58-67. doi: 10.1111/j.1939-165X.2004.tb00351.x.

18. Criswell KA, Bleavins MR, Zielinski D, Zandee JC. Comparison of flow cytometric and manual bone marrow differentials in Wistar rats. Cytometry 1998; 32: 9-17. doi: 10.1002/(SICI)10970320(19980501)32:1<3C9::AID-CYTO2>3.0.CO;2-I.

19. Criswell KA, BockJH, Wildeboer SE, Johnson K, Giovanelli RP. Validation of Sysmex XT-2000iV generated quantitative bone marrow differential counts in untreated Wistar rats. Vet Clin Pathol 2014; 43: 125-136. doi: 10.1111/vcp.12132.

20. Criswell KA, Bleavins MR, Zielinski D, Zandee JC, Walsh KM. Flow cytometric evaluation of bone marrow differentials in rats with pharmacologically induced hematologic abnormalities.
Cytometry 1998; 32: 18-27. doi: 10.1002/(SICI)10970320(19980501)32:1<18:AID-CYTO3>3.0.CO;2-B

21. Criswell KA, Bock JH, Wildeboer SE, Johnson K, Giovanelli RP. Comparison of the Sysmex XT-2000iV and microscopic bone marrow differential counts in Wistar rats treated with cyclophosphamide, erythropoietin, or serial phlebotomy. Vet Clin Pathol 2014; 43: 137-153. doi: 10.1111/vcp.12149.

22. Rosenthal RL, Pickering BI, Goldschmidt L. A semi-quantitative study of bone marrow in rats following total body X-irradiation. Blood 1951; 6: 600-613.

23. Peslak SA, Wenger J, Bemis JC, Kingsley PD, Frame JM, Koniski AD, et al. Sublethal radiation injury uncovers a functional transition during erythroid maturation. Exp Hematol. 2011; 39: 434-445. doi: 10.1016/j.exphem.2011.01.010.

24. Goldenberg GJ, Alexander P. The effects of nitrogen mustard and dimethyl myleran on murine leukemia cell lines of different radiosensitivity in vitro. Cancer Res 1965; 25: 1401-1409.

25. Hall EJ. Radiobiology for the radiologist, 5th ed. Philadelphia: Lippincott Williams \& Wilkins; 2000, $588 \mathrm{p}$.

26. Shevchuk OO, Posokhova KA, Sidorenko AS, Bardakhivska KI, Maslenny VM, Yushko LA, et al. The influence of enterosorption on some haematological and biochemical indices of the normal rats after single injection of melphalan. Exp Oncol 2014; 36: 94-100.

27. Shevchuk OO, Posokhova KA, Todor IN, Lukianova NY, Nikolaev VG, Chekhun VF. Prevention of myelosuppression by combined treatment with enterosorbent and granulocyte colony-stimulating factor. Exp Oncol 2015; 37: 135-138. 